\title{
Adsorption of methyl green dye onto multi-walled carbon nanotubes decorated with $\mathrm{Ni}$ nanoferrite
}

\author{
Mohamed Bahgat • Ahmed Ali Farghali • \\ Waleed El Rouby $\cdot$ Mohamed Khedr • \\ Mohassab Y. Mohassab-Ahmed
}

Received: 28 March 2012/Accepted: 23 April 2012/Published online: 11 May 2012

(C) The Author(s) 2012. This article is published with open access at Springerlink.com

\begin{abstract}
This research was carried out to evaluate the capability of multi-walled carbon nanotubes (CNTs) and $\mathrm{NiFe}_{2} \mathrm{O}_{4}$-decorated multi-walled carbon nanotubes $\left(\mathrm{NiFe}_{2}\right.$ $\mathrm{O}_{4}$-CNTs) toward waste water treatment relevant to organic dyes. CNTs were prepared via chemical vapor deposition method. $\mathrm{NiFe}_{2} \mathrm{O}_{4}$-CNTs were prepared by in-situ chemical precipitation of metal hydroxides followed by hydrothermal processing. The samples were characterized using XRD and TEM. The adsorption efficiency of CNTs and $\mathrm{NiFe}_{2} \mathrm{O}_{4}-\mathrm{CNTs}$ of methyl green dye at various temperatures was examined. The adsorbed amount increased with the CNTs and $\mathrm{NiFe}_{2} \mathrm{O}_{4}$ CNTs dosage. The linear correlation coefficients and standard deviations of Langmuir and Freundlich isotherms were determined. It was found that Langmuir isotherm fitted the experimental results well in both adsorption cases $n$ of methyl green onto CNTs and $\mathrm{NiFe}_{2} \mathrm{O}_{4}$-CNTs. Kinetics analyses were conducted using pseudo first-order, second-order and the intraparticle diffusion models. The results showed that the adsorption kinetics was controlled by a pseudo second-order model for adsorption of methyl green onto CNTs and best controlled by pseudo first-order in case of $\mathrm{NiFe}_{2} \mathrm{O}_{4}$-CNTs. Changes in the free energy of adsorption $\left(\Delta G^{\circ}\right)$, enthalpy $\left(\Delta H^{\circ}\right)$, entropy $\left(\Delta S^{\circ}\right)$, and the activation energy $\left(E_{\mathrm{a}}\right)$ were
\end{abstract}

\section{Bahgat}

Minerals Technology Department, Central Metallurgical R\&D Institute (CMRDI), Helwan, Egypt

A. A. Farghali - W. El Rouby - M. Khedr Chemistry Department, Faculty of Science, Beni-Suef University, Beni-Suef 62111, Egypt

M. Y. Mohassab-Ahmed ( $\square)$

Metallurgical Engineering Department, University of Utah,

Salt Lake City, UT 84112, USA

e-mail: mohassab.yousef@utah.edu determined. The $\Delta H^{\circ}, \Delta G^{\circ}$ and $E_{\mathrm{a}}$ values indicated that the adsorption of methyl green onto MWCNTs and $\mathrm{NiFe}_{2} \mathrm{O}_{4}$ MWCNTs was physisorption.

Keywords Carbon nanotubes - Decorated CNT · $\mathrm{NiFe}_{2} \mathrm{O}_{4} \cdot$ Adsorption · Methyl green · Isotherm

\section{Introduction}

Due to their unique physical and chemical properties (Treacy et al. 1996; Wildoer et al. (1998) and their immense potential for numerous applications (Liu et al. 1999; Kong et al. 2000), carbon nanotubes (CNTs) have attracted considerable attention. To date, much effort has been devoted to prepare and synthesize various composites of CNTs with metal and semiconductor nanoparticles (Liu et al. 2004; Yang et al. 2008a, b). Composite materials based on CNTs and inorganic nanomaterials integrate the unique characters and functions of the two types of components and may also exhibit some new properties due to the cooperative effects between the two kinds of materials (Hu and Dong 2008; Peng et al. 2009) Therefore, these composite materials have very attractive potential applications in many fields.

To optimize the potential applications of CNTs, it is essential to modify the CNTs with functional groups to enhance their properties. Of late, much more research has been conducted on decorating CNTs with iron oxide and preparing magnetic carbon nanomaterials. It is believed that such coated CNTS will have potential application in electric devices, magnetic data storage and heterogeneous catalysis. Various chemistry-based processing routes have been developed to synthesize $\mathrm{Fe}_{3} \mathrm{O}_{4}$-CNTs magnetic nanocomposites. Magnetic functionalization of CNTs was done by coating them with iron oxide nanoparticles through polymer

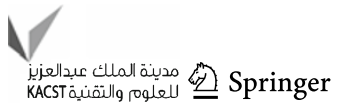


wrapping and layer-by-layer assembly techniques and then aligning the magnetic CNTs under low magnetic fields (Correa-Duarte et al. 2005). Also magnetic multi-walled CNTs were prepared based on the electrostatic attraction between the templated amino-functionalized CNTs and the magnetic $\mathrm{Fe}_{3} \mathrm{O}_{4}$ nanoparticles, and used as magnetic handles for the bio-manipulation of blood cells (Gao et al. 2006). Magnetite beads CNT composites were also synthesized through a hydrothermal approach (Jia et al. 2007).

CNTs are relatively new adsorbents that can remove trace pollutants from wastewater. CNTs have been proven to possess great potential for removing many different kinds of organic and inorganic pollutants such as dioxin (Long and Yang 2001) volatile organic compounds (Gauden et al. 2006) from air stream (Li et al. 2003), 1,2dichlorobenzene (Peng et al. 2003) and soil organic matters (Yang et al. 2006).

Magnetic separation technology combined with the adsorption process has been widely used in environmental purification applications. In general, magnetic adsorbents are often composed of magnetic nanoparticles dispersed in a crosslinked polymer matrix that is composed of both natural and synthetic polymer. It was reported that magnetic alginate microcapsule containing cyanex 272 could efficiently remove nickel ions from effluents (Ngomsik et al. 2006). Also magnetic-chitosan particle was used as magnetic adsorbent for the removal of fluoride (Ma et al. 2007). Arabic modified magnetic nano-adsorbent gum was studied for fast removal of copper ions (Banerjee and Chen 2007). Magnetic $\mathrm{Fe}_{3} \mathrm{O}_{4}$-activated carbon nanocomposite particles were developed for the removal of methylene blue from aqueous solutions (Yang et al. 2008a, b). Moreover a research group prepared magnetic alginate beads containing magnetic nanoparticles and activated carbon for the removal of organic dyes (Rocher et al. 2008).

In this paper, CNTs were prepared via chemical vapor deposition (CVD) method and decorated with $\mathrm{NiFe}_{2} \mathrm{O}_{4}$ by a hydrothermal precipitation method. The crystallographic structure of the prepared composites was investigated using XRD and TEM. Pure and decorated CNTs were evaluated as possible sorbents for the removal of methyl green dye from water. The effect of methyl green dye concentration, temperature, and contact time on the adsorption process was investigated. Kinetics and thermodynamic studies were performed.

\section{Experimental}

CNTs synthesis and purification

CNTs were produced by CVD of carbon from acetylene cracking over a $\mathrm{Fe}-\mathrm{Co} / \mathrm{CaCO}_{3}$ catalyst/support matrix. The method of synthesis was described elsewhere (Bahgat et al. 2011). The raw product contains $\mathrm{CaCO}_{3}$ support particles, $\mathrm{Fe}-\mathrm{Co}$ and a traces of amorphous carbons as impurities. This product was purified by via chemical oxidation method. In this method, $0.05 \mathrm{~g}$ of the as-grown CNTs was added to a mixture of concentrated nitric and sulfuric acids (3:1 v/v, respectively). The mixture was refluxed in an oil bath for $4 \mathrm{~h}$ at $120^{\circ} \mathrm{C}$, cooled to room temperature, diluted with distilled water and then filtered through a filter paper (3 $\mu \mathrm{m}$ porosity). This washing operation was repeated several times and then the mixture was dried at $100{ }^{\circ} \mathrm{C}$. All chemicals used were of analytical grade.

\section{Decoration of CNTs}

A weight of $0.05 \mathrm{~g}$ of the purified CNTs was first ultrasonicated in $100 \mathrm{ml}$ distilled water for $30 \mathrm{~min}$. Afterward, the suspension was mixed with solution of $\mathrm{Ni}\left(\mathrm{NO}_{3}\right)_{2} \cdot 6 \mathrm{H}_{2} \mathrm{O}$ and $\mathrm{Fe}\left(\mathrm{NO}_{3}\right)_{3} \cdot 9 \mathrm{H}_{2} \mathrm{O}$, in which the $\mathrm{Ni}: \mathrm{Fe}$ molar ratio was maintained at $1: 2$. Then, a sodium hydroxide solution (6 M) was added drop wise into the above mixture with vigorous stirring until the $\mathrm{pH}$ value reaches 10 . The mixture was stirred for another $30 \mathrm{~min}$ to ensure complete reaction and then the solution was neutralized using diluted $\mathrm{HCl}$. The product mixture was placed in a Teflon-lined autoclave maintained at $220{ }^{\circ} \mathrm{C}$ for $5 \mathrm{~h}$. The obtained precipitates were rinsed repeatedly with water and ethanol and dried at $100{ }^{\circ} \mathrm{C}$ for $12 \mathrm{~h}$ in a vacuum oven. The decorated CNTs were denoted as $\mathrm{NiFe}_{2} \mathrm{O}_{4}$-CNT composite.

\section{Characterization}

The phase structure of $\mathrm{Fe}-\mathrm{Co} / \mathrm{CaCO}_{3}$ catalyst/support powder was investigated by $\mathrm{X}$-ray phase analysis (PW 1730) with nickel filtered $\mathrm{Cu}$ radiation at $40 \mathrm{kV}$ and $30 \mathrm{~mA}$. The inner cavity, wall thickness and tube length of the CNTs were characterized using TEM (JEOL JEM1230) and SEM (Jeol JSM-5410). Functional groups that formed at oxidized CNTs surface were characterized by Fourier transform infrared spectroscopy (FTIR, JASCO 410). The BET surface area was determined from adsorption isotherms using a Quantachrome NOVA Automated Gas Sorption System Report.

\section{Adsorption activity}

Adsorption experiments were performed at $25{ }^{\circ} \mathrm{C}$ in an open borosilicate glass reactor of $250 \mathrm{ml}$ capacity whose temperature was regulated by thermostat. To determine the effects of dye concentration, the dye concentrations were 50,100 and $200 \mathrm{mg} / \mathrm{L}$ and $1 \mathrm{~g} / \mathrm{L}$ of CNTs and $\mathrm{NiFe}_{2} \mathrm{O}_{4}-$ $\mathrm{CNT}$ at $25{ }^{\circ} \mathrm{C}$. To determine the effect of adsorbent dosage, the adsorbent concentrations were $0.6,1$ and $1.4 \mathrm{~g} / \mathrm{L}$ 
and that of the dye was $100 \mathrm{mg} / \mathrm{L}$ and the temperature was $25{ }^{\circ} \mathrm{C}$. To examine the effect of temperature, the adsorbent concentration was $1 \mathrm{~g} / \mathrm{L}$ and dye was 50, 100, 200, 300 and $400 \mathrm{mg} / \mathrm{L}$ at temperatures of 25,40 and $50{ }^{\circ} \mathrm{C}$. After the equilibrium, suspensions were filtered to be analyzed for dye concentration. The amount of dye adsorbed at equilibrium $q_{\mathrm{e}}(\mathrm{mg} / \mathrm{g})$ was calculated from the following equation:

$q_{\mathrm{e}}=V\left(C_{0}-C_{\mathrm{e}}\right) / W$

where $C_{0}$ and $C_{\mathrm{e}}(\mathrm{mg} / \mathrm{L})$ are the liquid-phase concentrations of dye initially and at equilibrium, respectively. $V(\mathrm{~L})$ is the volume of the solution and $W(\mathrm{~g})$ is the used mass of adsorbent.

\section{Results and discussion}

Characterizations of synthesized materials

The FTIR spectra of as-prepared and surface-oxidized CNTs are shown in Fig. 1. The absence of hydroxyl groups and carbonyl groups in the as-prepared MWCNTs is obvious from the FTIR spectrum. On the other hand, characteristic bands due to generated polar functional groups are observed for CNTs oxidized in $\mathrm{H}_{2} \mathrm{SO}_{4} / \mathrm{HNO}_{3}$. These functional groups exist at the tip and on the outer shell of the tubes and make them easily dispersed in polar solvents, such as water, ethanol, etc (Liu et al. 1998).

Figure 2a shows a TEM image of CNTs prepared by CVD method at $600{ }^{\circ} \mathrm{C}$ and treated with the concentrated sulfuric acid/nitric acid mixtures $(3: 1 \mathrm{v} / \mathrm{v})$ for $4 \mathrm{~h}$ at $120{ }^{\circ} \mathrm{C}$. It shows that the CNTs have clear inner channel with a length of several microns. Figure $2 b$ shows TEM image of the CNTs decorated with $\mathrm{NiFe}_{2} \mathrm{O}_{4}$. It was found that $\mathrm{NiFe}_{2} \mathrm{O}_{4}$ covered the surface of CNTs. The hollow morphology of the carbon nanotubes is still identifiable and the average size of the $\mathrm{NiFe}_{2} \mathrm{O}_{4}$ nanoparticles is $11 \mathrm{~nm}$.

The XRD charts for pure CNTs, $\mathrm{NiFe}_{2} \mathrm{O}_{4}$ and $\mathrm{NiFe}_{2} \mathrm{O}_{4}$ CNTs are shown in Fig. 3. It shows that the characteristic XRD patterns for $\mathrm{NiFe}_{2} \mathrm{O}_{4}$ and MWCNTs are present in the $\mathrm{NiFe}_{2} \mathrm{O}_{4}$-CNT nanocomposite. The characteristic peaks of $\mathrm{NiFe}_{2} \mathrm{O}_{4}$ are found at $30.25^{\circ}, 35.62^{\circ}, 43.26^{\circ}, 57.36^{\circ}$ and $63.08^{\circ}$. This shows the formation of pure $\mathrm{NiFe}_{2} \mathrm{O}_{4}$ on MWCNTs without any contamination. Using Scherrer's formula, Eq. (2), the average crystallite size of the $\mathrm{NiFe}_{2} \mathrm{O}_{4}$ particles is estimated to be about $11 \mathrm{~nm}$, confirming TEM observation.

$D=0.89 \lambda / B \cos \theta$

where $\lambda=0.154056 \mathrm{~nm}, B$ is full peak width at half maximum value, and $\theta$ is the diffraction angle.

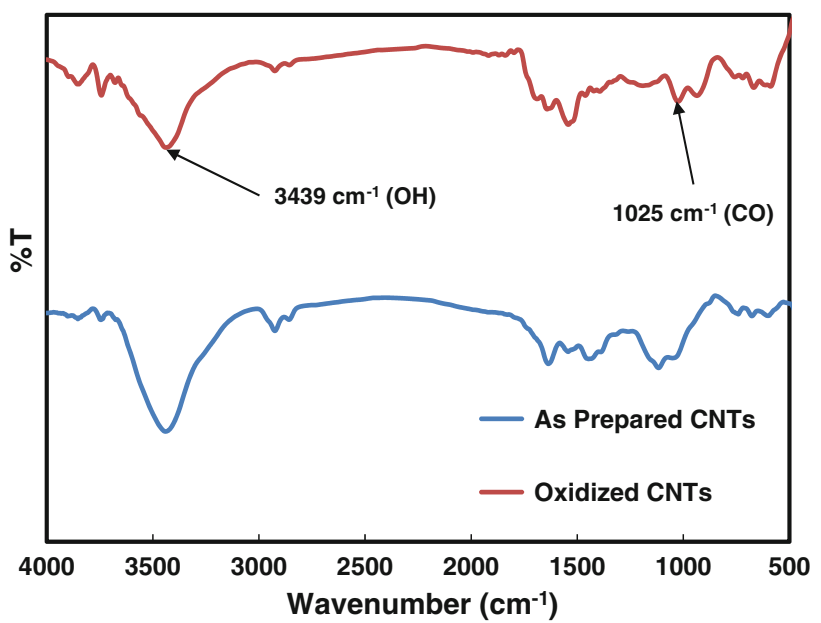

Fig. 1 FTIR spectra of as-prepared and oxidized CNTs
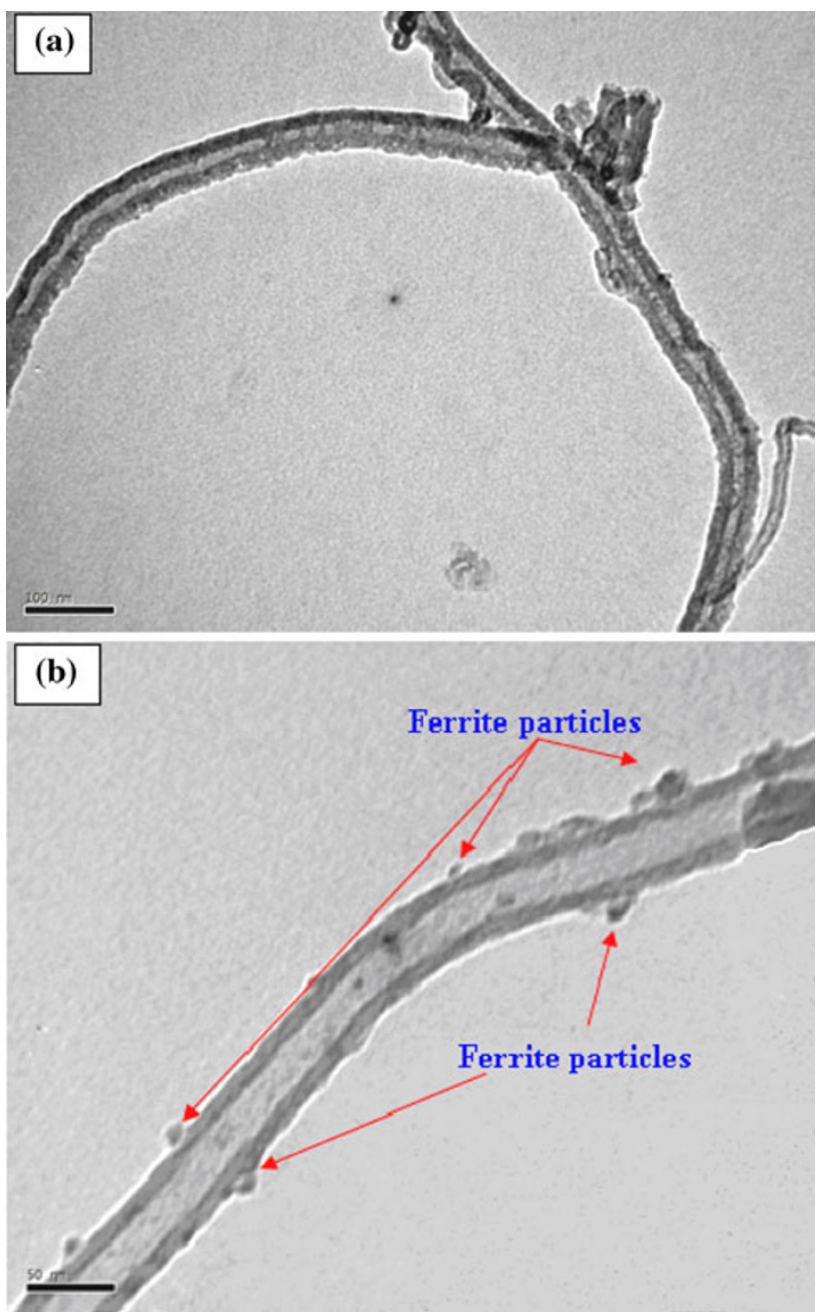

Fig. 2 TEM images of CNTs treated with acid mixture (a) and $\mathrm{NiFe}_{2} \mathrm{O}_{4}-\mathrm{CNT}$ (b)

Figure 4 shows the $\mathrm{N}_{2}$ adsorption-desorption isotherm of CNTs and $\mathrm{NiFe}_{2} \mathrm{O}_{4}$-CNTs decorated with nanoparticles. The adsorption isotherms exhibited a type II shape 


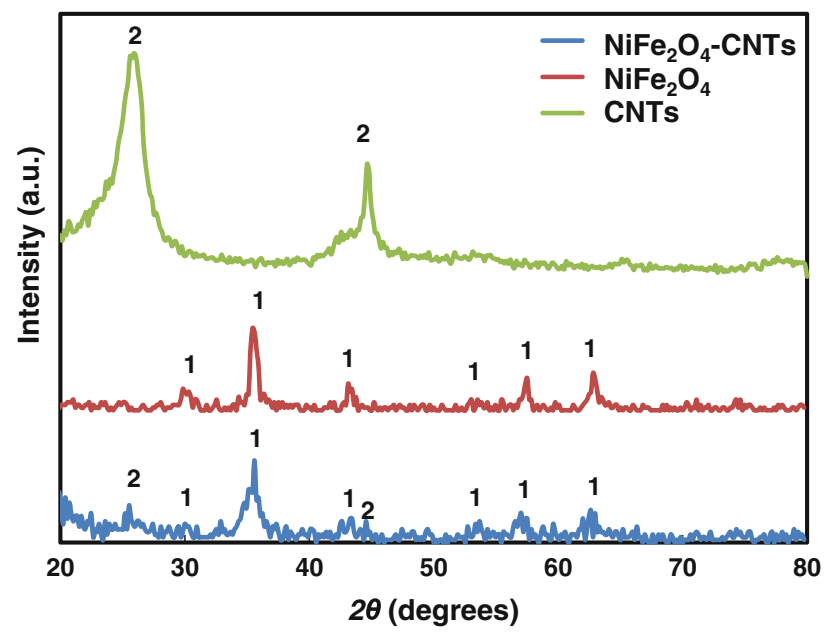

Fig. 3 XRD patterns of CNTs, $\mathrm{NiFe}_{2} \mathrm{O}_{4}$ and $\mathrm{NiFe}_{2} \mathrm{O}_{4}$-CNTs composite ( $1 \mathrm{NiFe}_{2} \mathrm{O}_{4}$ and 2 Graphite)

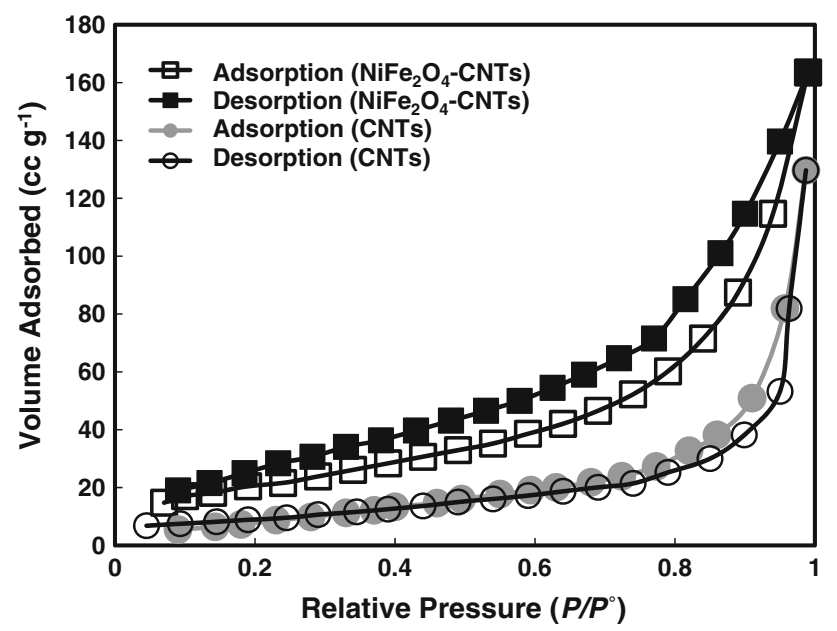

Fig. $4 \mathrm{~N}_{2}$ adsorption/desorption isotherms of CNTs and $\mathrm{NiFe}_{2} \mathrm{O}_{4^{-}}$ CNTs

according to IUPAC classification (Gregg and Sing 1982). It was observed that there was a small closed adsorptiondesorption hysteresis loop, which might be due to mesopore capillary condensation (Bansal 2005).

The BET surface area, the average pore diameter, and the average pore volume of CNTs were $35.5 \mathrm{~m}^{2} / \mathrm{g}, 19.6 \mathrm{~nm}$ and $0.017 \mathrm{~cm}^{3} / \mathrm{g}$, respectively, while those of $\mathrm{NiFe}_{2} \mathrm{O}_{4^{-}}$ MWCNTs were $73.9 \mathrm{~m}^{2} / \mathrm{g}, 19.4 \mathrm{~nm}$, and $0.039 \mathrm{~cm}^{3} / \mathrm{g}$, respectively. The large hysteresis area indicates the nearly uniform distribution of pores and large surface area of CNTs decorated with $\mathrm{NiFe}_{2} \mathrm{O}_{4}$ nanoparticles. It can be seen that the surface area increased when $\mathrm{NiFe}_{2} \mathrm{O}_{4}$ nanoparticles attached to CNTs surface due to the added surface area of the $\mathrm{NiFe}_{2} \mathrm{O}_{4}$ nanoparticles. On the contrary, the average pore diameter decreased after decoration which could be attributed to the attached $\mathrm{NiFe}_{2} \mathrm{O}_{4}$ nanoparticles blocking the pores on the CNTs surface.
Adsorption of organic dye

To study the adsorption behavior of methyl green onto CNTs and $\mathrm{NiFe}_{2} \mathrm{O}_{4}-\mathrm{CNTs}$, concentrations of $0.6,1.0$ and $1.4 \mathrm{~g} / \mathrm{L}$ of the adsorbent were used to adsorb methyl green from the aqueous solution as shown in Fig. 5. After $120 \mathrm{~min}$ of adsorption time, percent ( $\%$ adsorption) of methyl green onto CNTs was 30.8, 51.9 and 59.4 as the CNTs concentration increased from $0.6,1.0$ and $1.4 \mathrm{~g} / \mathrm{L}$, respectively. While in case of $\mathrm{NiFe}_{2} \mathrm{O}_{4}$-CNTs, the adsorption percent reached 28.08, 49.35 and 56.19 for composite concentrations of 0.6, 1.0 and $1.4 \mathrm{~g} / \mathrm{L}$, respectively. Percent of adsorption increases with CNTs or $\mathrm{NiFe}_{2} \mathrm{O}_{4}$-MWCNTs concentration due to increase of adsorbent surface area and adsorption sites availability. Figure 6 shows the variation of adsorption percent of methyl green with time for different initial dye concentrations. The initial concentration plays an important role in the adsorption capacity of the dye on CNTs and $\mathrm{NiFe}_{2} \mathrm{O}_{4}$-CNTs. The amount of adsorbed dye per unit of CNTs and $\mathrm{NiFe}_{2} \mathrm{O}_{4}$-MWCNTs mass increased with initial dye concentration due to the increase in concentration gradient which the mass transfer driving force.

Evaluation of equilibrium adsorption isotherm

The adsorption equilibrium isotherm is important for describing how the adsorbate molecules distribute between the liquid and the solid phases, the adsorbent, when the adsorption process reaches an equilibrium state. The adsorption isotherms of methyl green on the CNTs and $\mathrm{NiFe}_{2} \mathrm{O}_{4}$-MWCNTs at 25,40 and $50{ }^{\circ} \mathrm{C}$ are shown in Fig. 7. The equilibrium uptake increased with methyl green concentration since the active sites of the CNTs or $\mathrm{NiFe}_{2} \mathrm{O}_{4}$-MWCNTs are surrounded by many more methyl

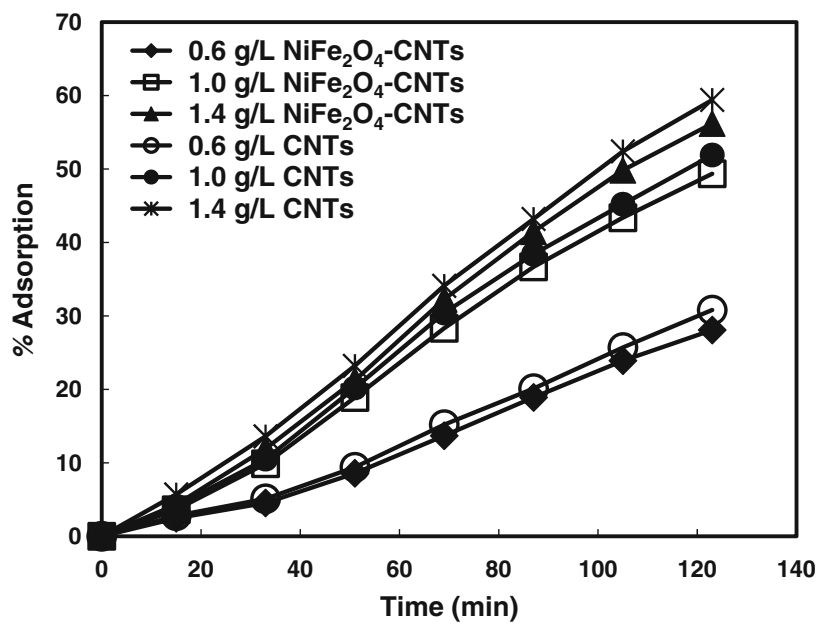

Fig. 5 Effect of CNTs and $\mathrm{NiFe}_{2} \mathrm{O}_{4}$-CNTs concentrations on the adsorption of methyl green dye at dye concentration of $100 \mathrm{mg} / \mathrm{L}$ and $25^{\circ} \mathrm{C}$ 


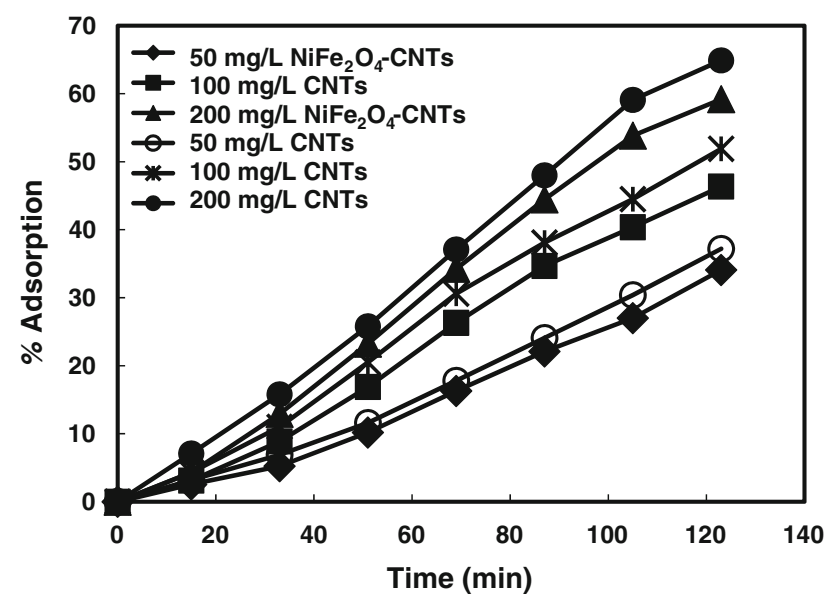

Fig. 6 Effect of dye concentration on the adsorption of methyl green dye at CNTs and $\mathrm{NiFe}_{2} \mathrm{O}_{4}$-CNTs concentrations of $1 \mathrm{~g} / \mathrm{L}$ and $25^{\circ} \mathrm{C}$

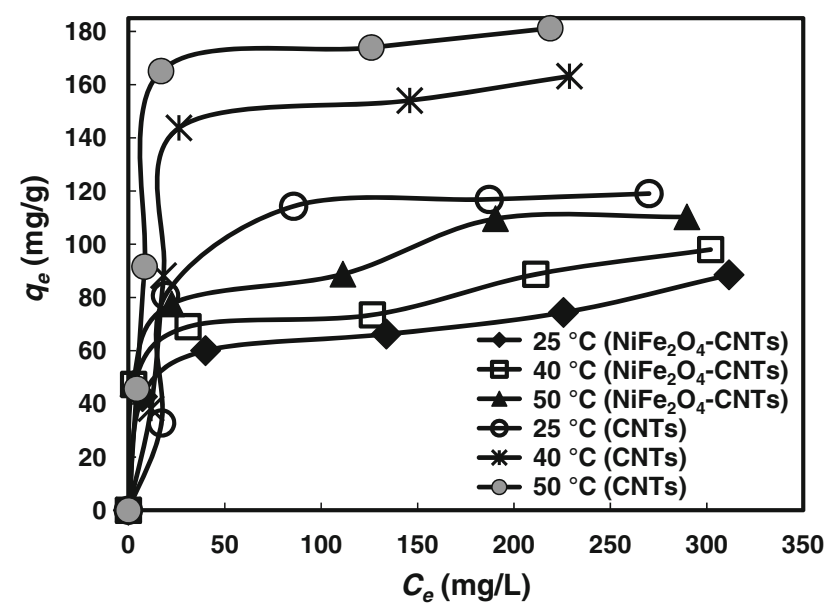

Fig. 7 Adsorption isotherms of methyl green onto CNTs and $\mathrm{NiFe}_{2} \mathrm{O}_{4}$-CNTs at different temperatures

green ions. Therefore, the values of $q_{\mathrm{e}}$ increase with the values of equilibrium methyl green concentrations. Figure 7 shows that the adsorption capacities of methyl green onto the CNTs were $119.05,160.12$ and $181.2 \mathrm{mg} / \mathrm{g}$ at 25,40 and $50{ }^{\circ} \mathrm{C}$, respectively, while those of $\mathrm{NiFe}_{2} \mathrm{O}_{4}$-CNTs were $88.5,98.02$ and $110.3 \mathrm{mg} / \mathrm{g}$, respectively. The adsorption capacity of CNTs is higher than the adsorption capacity of $\mathrm{NiFe}_{2} \mathrm{O}_{4}$-CNTs despite its relatively higher surface area. This is due to the numerous chemical sorption sites formed as a result of functionalization (acid treatment) of CNTs surface while in case of $\mathrm{NiFe}_{2} \mathrm{O}_{4}$-CNTs the attached $\mathrm{NiFe}_{2} \mathrm{O}_{4}$ nanoparticles may block the active sites and function groups on CNTs surface.

The increase of the equilibrium adsorption with temperature indicated that the adsorption of methyl green ions onto CNTs and $\mathrm{NiFe}_{2} \mathrm{O}_{4}$-CNTs was endothermic in nature.
At equilibrium, no change could be observed in the solute concentration on either the solid surface or in the bulk solution, regardless of the system's solute, adsorbent, solvent, and temperature which ensures equilibrium attainment. The isotherm data were fitted to the Langmuir and Freundlich isotherms (LeVan and Vermeulen 1981). The Langmuir model (Langmuir 1918) assumes that there is no interaction between the adsorbate molecules and that adsorption is localized in a monolayer. The Langmuir isotherm is represented by the following linear equation:

$C_{\mathrm{e}} / q_{\mathrm{e}}=1 /\left(q_{\mathrm{o}} K_{\mathrm{L}}\right)+\left(1 / q_{\mathrm{o}}\right) C_{\mathrm{e}}$

where $C_{\mathrm{e}}(\mathrm{mg} / \mathrm{L})$ is the equilibrium concentration, $q_{\mathrm{e}}(\mathrm{mg} / \mathrm{g})$ is the amount of adsorbate adsorbed per unit mass of adsorbate, and $q_{0}$ and $K_{\mathrm{L}}$ are the Langmuir constants related to the adsorption capacity and the rate of adsorption, respectively. When $C_{\mathrm{e}} / q_{\mathrm{e}}$ was plotted against $C_{\mathrm{e}}$, a straight line with a slope of $1 / q_{0}$ was obtained, as shown in Fig. 8a, b, indicating that the adsorption of methyl green on CNTs and $\mathrm{NiFe}_{2} \mathrm{O}_{4}$-CNTs follows the Langmuir isotherm. The Langmuir constants $K_{\mathrm{L}}$ and $q_{0}$ were calculated from this isotherm and their values are listed in Table 1. Another important parameter, $R_{\mathrm{L}}$, called the separation factor or the equilibrium parameter, is evaluated in this study and determined from the following relation (Hall et al. 1966):

$R_{\mathrm{L}}=1 /\left[1+K_{\mathrm{L}} C_{0}\right]$

where $K_{\mathrm{L}}$ is the Langmuir constant $(1 / \mathrm{mg})$ and $C_{0}(\mathrm{mg} / \mathrm{L})$ is the highest dye concentration. The value of $R_{\mathrm{L}}$ indicates whether adsorption will be unfavorable $\left(R_{\mathrm{L}}>1\right)$, linear $\left(R_{\mathrm{L}}=1\right)$, favorable $\left(0<R_{\mathrm{L}}<1\right)$ or irreversible $\left(R_{\mathrm{L}}=0\right) . R_{\mathrm{L}}$ values of methyl green adsorption onto CNTs and $\mathrm{NiFe}_{2} \mathrm{O}_{4}$ MWCNTs were calculated. The $R_{\mathrm{L}}$ values were between one and zero indicating favorable adsorption (Table 1). The langmuir equation fitted the data of the adsorption of methyl green onto both pure and decorated CNTs with $R^{2}$ values more than 0.99 , indicating that the formation of a monolayer of dye molecules was predominant.

The Freundlich isotherm model is an empirical relationship describing the adsorption of solutes from a liquid to a solid surface, and assumes that different sites with several adsorption energies are involved. The linear form of the Freundlich equation is the following:

$\ln q_{\mathrm{e}}=\ln K_{\mathrm{F}}+(1 / n) \ln C_{\mathrm{e}}$

where $q_{\mathrm{e}}$ is the amount adsorbed at equilibrium $(\mathrm{mg} / \mathrm{g})$ and $C_{\mathrm{e}}$ is the equilibrium concentration of methyl green. $K_{\mathrm{F}}$ and $n$ are Freundlich constants, where $K_{\mathrm{F}}\left(\mathrm{mg} / \mathrm{g}(\mathrm{L} / \mathrm{mg})^{1 / n}\right)$ is the adsorption capacity of the adsorbent and $n$ giving an indication of how favorable the adsorption process. Figure $8 \mathrm{c}, \mathrm{d}$ shows the linear relationship between $\ln q_{\mathrm{e}}$ and $\ln C_{\mathrm{e}}$, indicating that the adsorption of methyl green onto CNTs and $\mathrm{NiFe}_{2} \mathrm{O}_{4}$-CNTs also follows the Freundlich isotherm. 

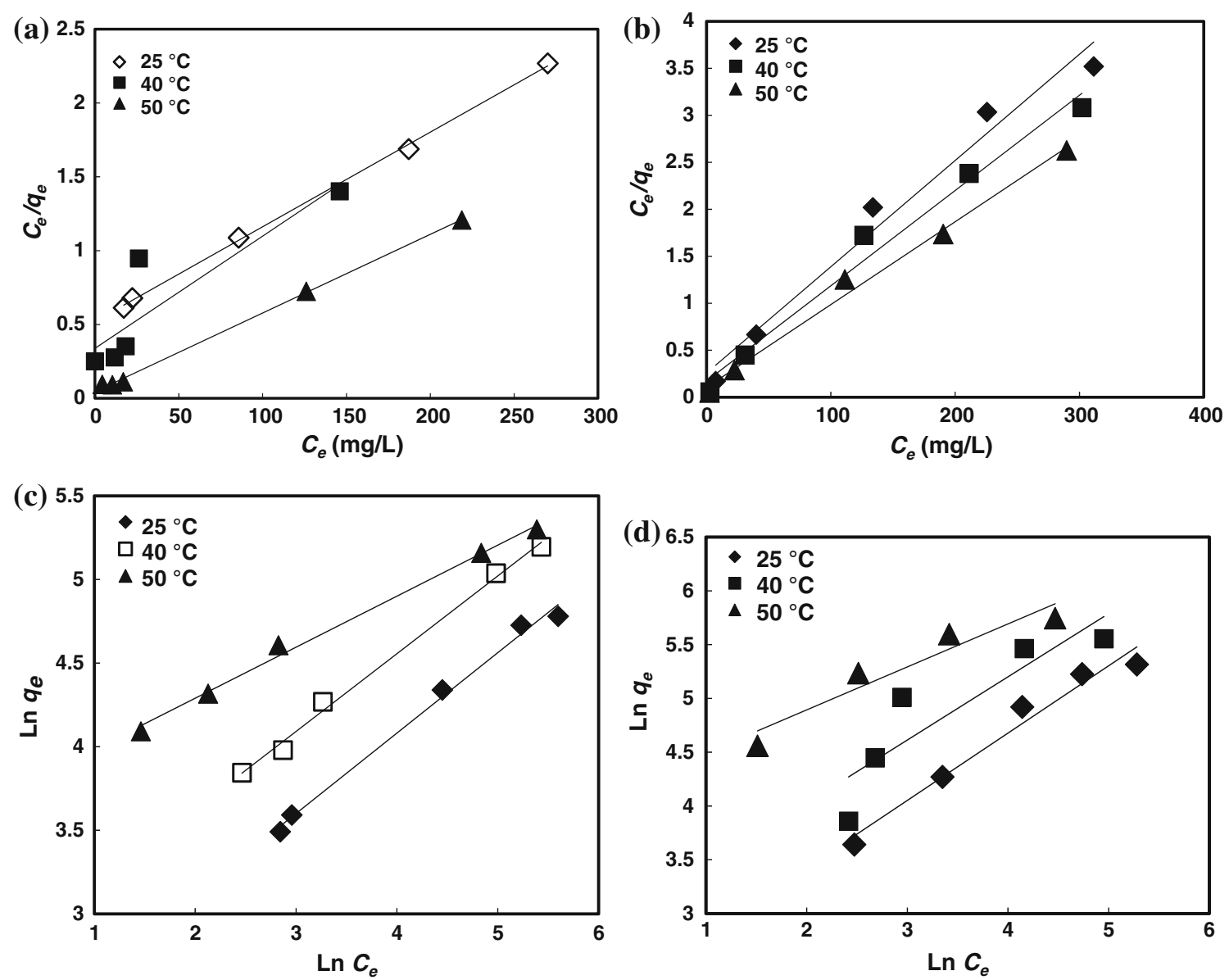

Fig. 8 Langmuir isotherm of dye adsorption at different temperatures onto CNTs (a) and $\mathrm{NiFe}_{2} \mathrm{O}_{4}-\mathrm{CNTs}$ (b) and Freundlich isotherm of dye adsorption at different temperatures onto CNTs (c) and $\mathrm{NiFe}_{2} \mathrm{O}_{4}-\mathrm{CNTs}(\mathbf{d})$

Table 1 Isotherm parameters for removal of methyl green by CNTs and CNTs- $\mathrm{NiFe}_{2} \mathrm{O}_{4}$ at different temperatures

\begin{tabular}{|c|c|c|c|c|c|c|c|}
\hline \multirow[t]{3}{*}{ Isotherm } & \multirow[t]{3}{*}{ Parameters } & \multicolumn{6}{|c|}{ Temperature } \\
\hline & & \multicolumn{3}{|l|}{$\mathrm{CNT}$} & \multicolumn{3}{|c|}{$\mathrm{NiFe}_{2} \mathrm{O}_{4}-\mathrm{CNTs}$} \\
\hline & & $25^{\circ} \mathrm{C}$ & $40{ }^{\circ} \mathrm{C}$ & $50^{\circ} \mathrm{C}$ & $25^{\circ} \mathrm{C}$ & $40{ }^{\circ} \mathrm{C}$ & $50{ }^{\circ} \mathrm{C}$ \\
\hline \multirow[t]{4}{*}{ Langmuir } & $q_{0}(\mathrm{mg} / \mathrm{g})$ & 146 & 187 & 190 & 88.495 & 99.01 & 113.43 \\
\hline & $K_{\mathrm{L}}(\mathrm{L} / \mathrm{mg})$ & 0.017 & 0.028 & 0.06 & 0.0437 & 0.0585 & 0.0854 \\
\hline & $R_{\mathrm{L}}$ & 0.13 & 0.082 & 0.04 & 0.054 & 0.041 & 0.028 \\
\hline & $R^{2}$ & 0.998 & 0.999 & 0.998 & 0.99 & 0.991 & 0.992 \\
\hline \multirow[t]{3}{*}{ Freundlich } & $K_{\mathrm{F}}\left(\mathrm{mg} / \mathrm{g}(\mathrm{L} / \mathrm{mg})^{1 / n}\right)$ & 8.58 & 14.73 & 39.6 & 8.758 & 17.24 & 61.123 \\
\hline & $n$ & 2.08 & 2.15 & 3.27 & 1.59 & 1.7 & 2.54 \\
\hline & $R^{2}$ & 0.992 & 0.995 & 0.994 & 0.967 & 0.80 & 0.968 \\
\hline
\end{tabular}

Accordingly, Freundlich constants $\left(K_{\mathrm{F}}\right.$ and $\left.n\right)$ were calculated and listed in Table 1.

Evaluation of adsorption kinetics

Adsorption is a physicochemical process that involves mass transfer of a solute from the buck of the solution to the adsorbent surface. Kinetics analysis provided important information about the mechanism of methyl green adsorption onto CNTs and $\mathrm{NiFe}_{2} \mathrm{O}_{4}$-CNTs composite, which was necessary to depict the adsorption rate of adsorbate and control the residual time of the whole adsorption process. The temperature effect on process kinetics was evaluated, as shown in Fig. 9. The adsorption 

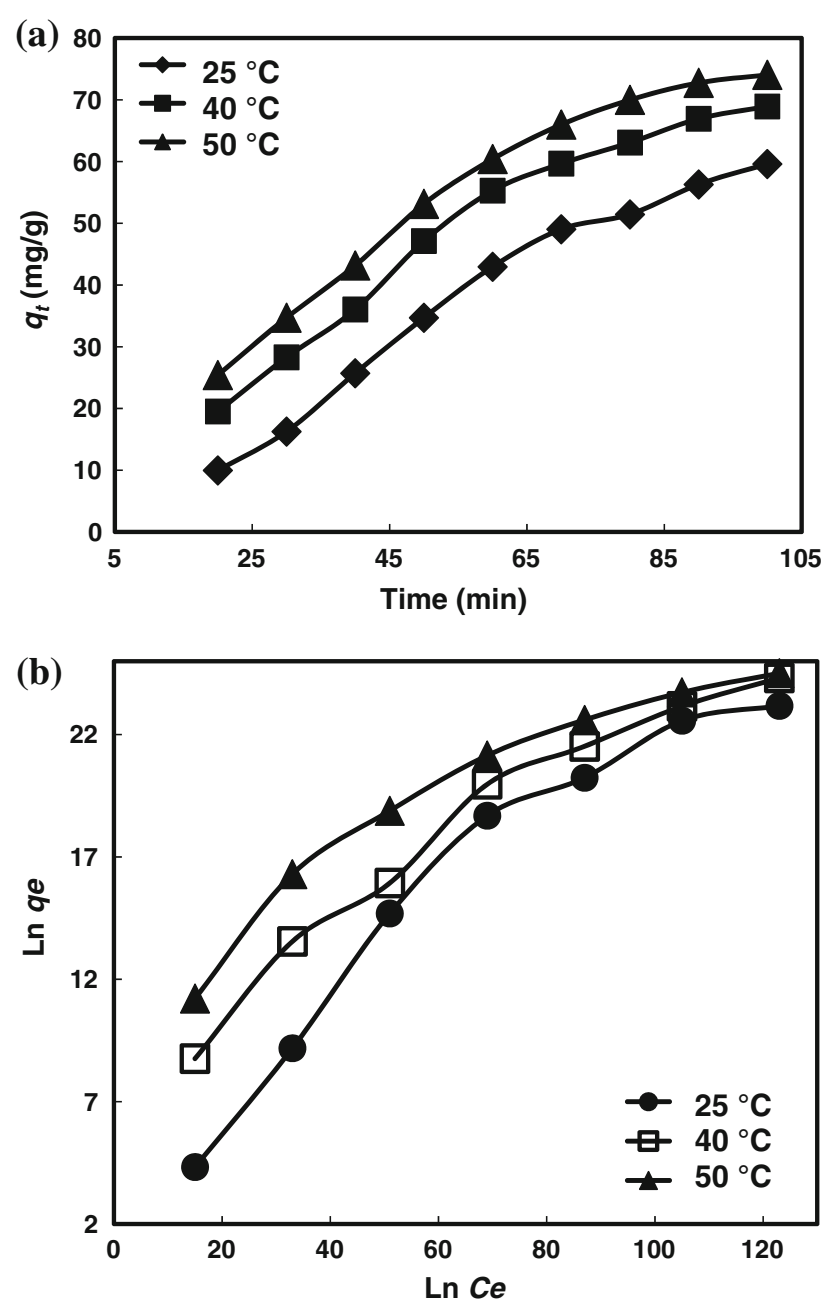

Fig. 9 Effect of temperature on adsorption kinetics of methyl green of $100 \mathrm{mg} / \mathrm{L}$ onto CNTs of $1 \mathrm{~g} / \mathrm{L}$ (a) and $\mathrm{NiFe}_{2} \mathrm{O}_{4}-\mathrm{CNTs}$ of $1 \mathrm{~g} / \mathrm{L} \mathrm{(b)}$

is initially rapid, and then slows. A large number of vacant surface sites are available for adsorption during the initial stage and then the adsorption decreases gradually due to the repulsive forces between the dye molecules on the CNTs, $\mathrm{NiFe}_{2} \mathrm{O}_{4}-\mathrm{CNT}$ and the bulk phase (Mall et al. 2006). Increasing the temperature reduces the viscosity of the solution and increases the diffusion rate of dye molecules.

Three of the most widely used kinetics models: pseudofirst-order, pseudo-second-order and intra-particle diffusion models were used to examine the adsorption kinetics behavior of methyl green onto CNTs and $\mathrm{NiFe}_{2} \mathrm{O}_{4}$-CNTs composite. The best-fit model was selected based on the linear regression correlation coefficient values $\left(R^{2}\right)$. The pseudo-first-order kinetics model might be represented by the following equation (Demirbas et al. 2009):

$\ln \left(q_{\mathrm{e}}-q\right)=\ln \left(q_{\mathrm{e}}\right)-k_{1} t$

where $q_{e}$ and $q(\mathrm{mg} / \mathrm{g})$ are the amounts of methyl green adsorbed onto CNTs and $\mathrm{NiFe}_{2} \mathrm{O}_{4}$-CNTs composite at equilibrium at any given time, $t(\min )$, and $k_{1}\left(\min ^{-1}\right)$ is the rate constant of the pseudo-first-order model for the adsorption. The values of $q_{e}$ and $k_{1}$ can be determined from the intercept and slope of the linear plot of $\ln \left(q_{e}-q\right)$ versus $t$. A linear form of pseudo-second-order kinetics model is expressed by the following equation (Feng et al. 2009:

$(t / q)=1 /\left(k_{2} q_{\mathrm{e}}^{2}\right)+\left(t / q_{\mathrm{e}}\right)$

where $q_{\mathrm{e}}$ and $q$ are the same as defined in the pseudo-firstorder model; $k_{2}$ is the rate constant of the pseudo secondorder model for adsorption (g/mg.min). The slope and intercept of the linear plot of $t / q$ against $t$ yielded the values of $q_{\mathrm{e}}$ and $k_{2}$.

An intra-particle mass transfer diffusion model was proposed as (Weber and Morris 1963):

$q=k_{\mathrm{i}} t^{1 / 2}+C$

where $C$ is the intercept and $k_{\mathrm{i}}$ is the intraparticle diffusion rate constant $\left(\mathrm{mg} / \mathrm{g} \mathrm{min}^{1 / 2}\right)$, which can be evaluated from the slope of the plot of $q$ versus $t^{1 / 2}$.

Plots of pseudo-first-order and second-order kinetics models are shown in Fig. 10a-d. Table 2 lists the coefficients of the pseudo-first and second-order adsorption kinetics models and the intraparticle diffusion model. The plots of $t / q_{t}$ versus $t$ show good agreement between experimental $\left(q_{\mathrm{e}, \mathrm{exp}}\right)$ and calculated $\left(q_{\mathrm{e}, \mathrm{cal}}\right)$ values in case of methyl green adsorption onto CNTs. Furthermore, the correlation coefficients for the second-order kinetics model $\left(R^{2}\right)$ are greater than 0.99 . Thus, the kinetics of the adsorption of methyl green onto CNTs could be described by the second-order kinetics model. This adsorption process may involve the sharing of electrons between anions (Dye) and the adsorbent (CNTs). On the other hand, the pseudo-first-order kinetics model was more valid in describing the adsorption kinetics of methyl green onto $\mathrm{NiFe}_{2} \mathrm{O}_{4}$-CNTs composite as revealed from its higher correlation coefficient values $\left(R^{2}>0.98\right)$ and closer values between $q_{e, \text { cal }}$ and $q_{e, \exp }$ as shown in Table 2 .

For the intra-particle diffusion model, the larger the intercept, the greater the surface adsorption contributes to the rate-controlling step. All the intercepts of the plots showed the boundary layer effect, as shown in Fig. 10e, f and Table 2, as well as all the correlation coefficients were low. Also all the linear portions did not pass through the origin, as shown in Fig. 10e, f indicating that intra-particle diffusion was not the only rate-controlling step (Ho and McKay 2003).

Adsorption thermodynamics

To estimate the effect of temperature on the adsorption of methyl green onto $\mathrm{NiFe}_{2} \mathrm{O}_{4}-\mathrm{CNTs}$, the standard free energy 

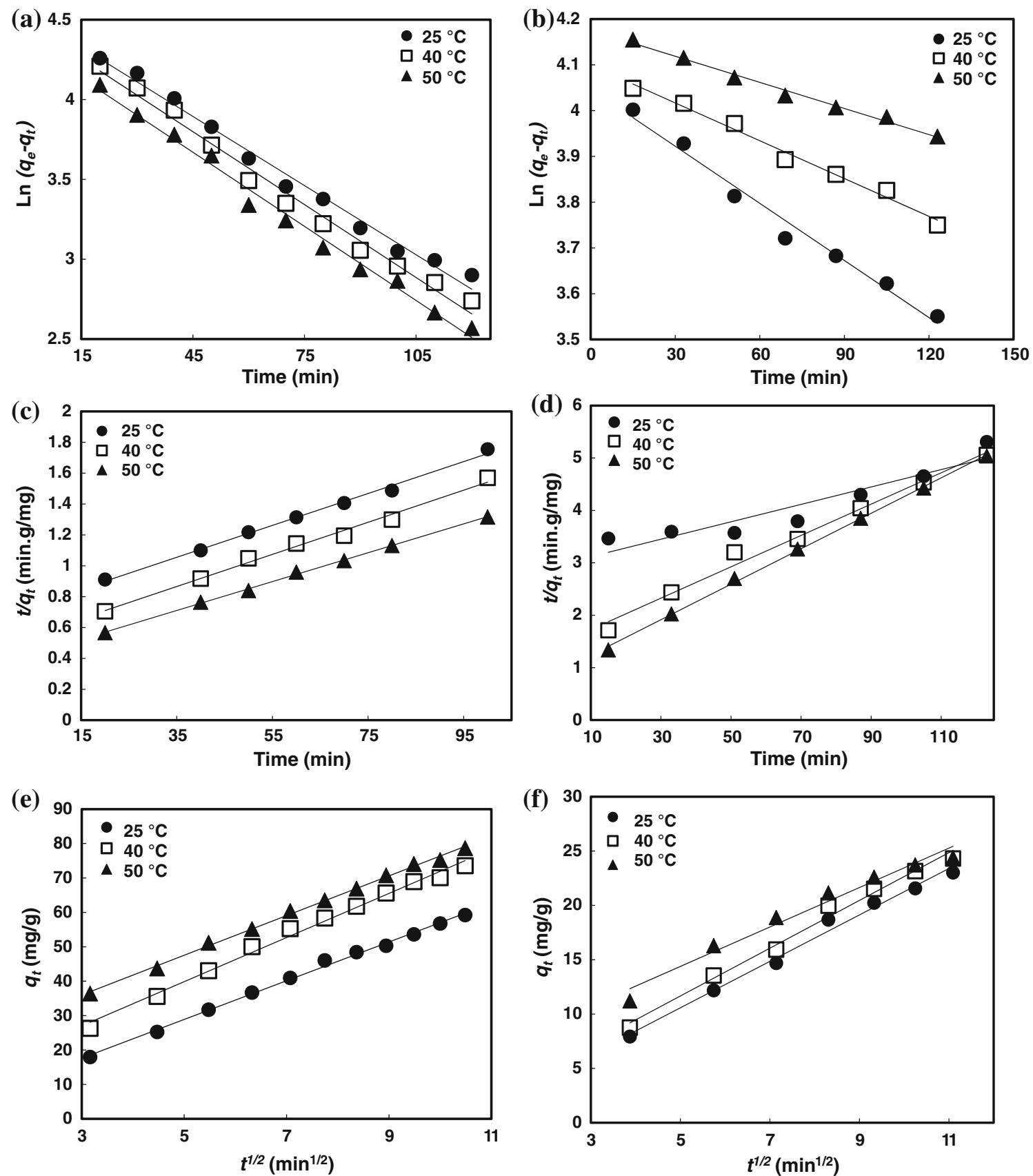

Fig. 10 Kinetics model at different temperatures. Pseudo-first-order model in case of CNTs (a) and $\mathrm{NiFe}_{2} \mathrm{O}_{4}$-CNTs (b). Pseudo-second-order model in case of CNTs (c) and $\mathrm{NiFe}_{2} \mathrm{O}_{4}$-CNTs (d). Intraparticle diffusion model for CNTs (e) and $\mathrm{NiFe}_{2} \mathrm{O}_{4}$-CNTs (f)

change $\left(\Delta G^{\circ}\right)$, enthalpy change $\left(\Delta H^{\circ}\right)$, and entropy change $\left(\Delta S^{\circ}\right)$ were determined. The Langmuir isotherm (Langmuir 1918) was used to calculate thermodynamic parameters using the following equations:

$$
\begin{aligned}
& \Delta G^{\circ}=-\mathrm{RT} \ln \left(K_{\mathrm{L}}\right) \\
& \ln \left(K_{\mathrm{L}}\right)=\left(\Delta S^{\circ} / R\right)-\left(\Delta H^{\circ} / R T\right)
\end{aligned}
$$

where $K_{\mathrm{L}}$ is the Langmuir equilibrium constant $(\mathrm{L} / \mathrm{mol}) ; R$ is the gas constant $(8.314 \mathrm{~J} / \mathrm{mol} \mathrm{K})$; and $T$ is temperature $(\mathrm{K})$.
Considering the relationship between $\Delta G^{\circ}$ and $K_{\mathrm{L}}, \Delta H^{\circ}$ and $\Delta S^{\circ}$ were determined from the slope and intercept of the van't Hoff plots of $\ln \left(K_{\mathrm{L}}\right)$ versus $1 / T$. Table 3 presents the thermodynamic parameters of methyl green adsorption onto pure and decorated CNTs at various temperatures. The adsorption of methyl green increases with temperature, indicating that $\Delta H^{\circ}$ is positive. The positive $\Delta H^{\circ}$ value shows that the absorption process is endothermic for methyl green, suggesting a strong attractive force between the 
Table 2 Parameters of pseudo-first and second-order kinetics models and intraparticle diffusion model (methyl green $=100 \mathrm{mg} / \mathrm{L}$, CNT and $\mathrm{NiFe}_{2} \mathrm{O}_{4}-\mathrm{CNTs}=1 \mathrm{~g} / \mathrm{L}$ )

\begin{tabular}{|c|c|c|c|c|c|c|c|}
\hline \multirow[t]{3}{*}{ Orders model } & \multirow[t]{3}{*}{ Parameters } & \multicolumn{6}{|c|}{ Temperature } \\
\hline & & \multicolumn{3}{|l|}{ CNTs } & \multicolumn{3}{|c|}{$\mathrm{NiFe}_{2} \mathrm{O}_{4}-\mathrm{CNTs}$} \\
\hline & & $25^{\circ} \mathrm{C}$ & $40^{\circ} \mathrm{C}$ & $50^{\circ} \mathrm{C}$ & $25^{\circ} \mathrm{C}$ & $40{ }^{\circ} \mathrm{C}$ & $50{ }^{\circ} \mathrm{C}$ \\
\hline \multirow[t]{4}{*}{ Pseudo-first-order model } & $q_{\mathrm{e}, \mathrm{cal}}(\mathrm{mg} / \mathrm{g})$ & 93.69 & 88.23 & 78.7 & 57.2 & 60.28 & 63.24 \\
\hline & $q_{\mathrm{e}, \exp }(\mathrm{mg} / \mathrm{g})$ & 80.729 & 88.17 & 91.6 & 59.99 & 69.022 & 77.57 \\
\hline & $k_{1}\left(\min ^{-1}\right)$ & 0.0144 & 0.0152 & 0.0155 & 0.00196 & 0.00275 & 0.0039 \\
\hline & $R^{2}$ & 0.988 & 0.987 & 0.987 & 0.981 & 0.986 & 0.989 \\
\hline \multirow[t]{4}{*}{ Pseudo-second-order model } & $q_{\mathrm{e}, \mathrm{cal}}(\mathrm{mg} / \mathrm{g})$ & 83.3 & 90.9 & 95.6 & 60.24 & 33.44 & 29.58 \\
\hline & $q_{\mathrm{e}, \exp }(\mathrm{mg} / \mathrm{g})$ & 80.729 & 88.17 & 91.6 & 59.99 & 69.022 & 77.57 \\
\hline & $k_{2}(\mathrm{~g} / \mathrm{mg} \min )$ & 0.00021 & 0.00024 & 0.00028 & $9.31 \times 10^{-6}$ & $6.26 \times 10^{-4}$ & $1.27 \times 10^{-3}$ \\
\hline & $R^{2}$ & 0.994 & 0.995 & 0.998 & 0.90 & 0.98 & 0.988 \\
\hline \multirow[t]{3}{*}{ Intraparticle diffusion model } & $k_{\mathrm{i}}\left(\mathrm{mg} / \mathrm{g} \min ^{0.5}\right)$ & 5.628 & 6.41 & 5.76 & 2.747 & 2.197 & 1.81 \\
\hline & $\mathrm{C}(\mathrm{mg} / \mathrm{g})$ & 0.735 & 7.79 & 18.7 & 0.0154 & 0.672 & 5.31 \\
\hline & $R^{2}$ & 0.996 & 0.992 & 0.997 & 0.989 & 0.988 & 0.972 \\
\hline
\end{tabular}

Table 3 Thermodynamic parameters of adsorption of methyl green dye onto CNTs and $\mathrm{NiFe}_{2} \mathrm{O}_{4}$-CNTs at various temperatures

\begin{tabular}{|c|c|c|c|c|c|c|c|c|}
\hline \multirow[t]{2}{*}{$\mathrm{T}\left({ }^{\circ} \mathrm{C}\right)$} & \multicolumn{4}{|l|}{ CNTs } & \multicolumn{4}{|c|}{$\mathrm{NiFe}_{2} \mathrm{O}_{4}-\mathrm{CNTs}$} \\
\hline & $\begin{array}{l}\Delta G^{\circ} \\
(\mathrm{kJ} / \mathrm{mol})\end{array}$ & $\begin{array}{l}\Delta H^{\circ} \\
(\mathrm{kJ} / \mathrm{mol})\end{array}$ & $\begin{array}{l}\Delta S^{\circ} \\
(\mathrm{J} / \mathrm{mol} \mathrm{K})\end{array}$ & $\begin{array}{l}E_{a} \\
(\mathrm{~kJ} / \mathrm{mol})\end{array}$ & $\begin{array}{l}\Delta G^{\circ} \\
(\mathrm{kJ} / \mathrm{mol})\end{array}$ & $\begin{array}{l}\Delta H^{\circ} \\
(\mathrm{kJ} / \mathrm{mol})\end{array}$ & $\begin{array}{l}\Delta S^{\circ} \\
(\mathrm{J} / \mathrm{mol} \mathrm{K})\end{array}$ & $\begin{array}{l}E_{\mathrm{a}} \\
(\mathrm{kJ} / \mathrm{mol})\end{array}$ \\
\hline 25 & -5.09 & 38.9 & 45.336 & 8.98 & -7.43 & 20.83 & 94.57 & 21.4 \\
\hline 40 & -6.64 & & & & -8.56 & & & \\
\hline 50 & -8.9 & & & & -9.85 & & & \\
\hline
\end{tabular}

adsorbents and methyl green. For methyl green ions to travel through solution and reach the adsorption sites, it is necessary for them first to be stripped out of their hydration shell (at least partially) which requires energy input. If the attractive force associated with the adsorption of methyl green onto the adsorbents does not exceed the dehydration energy of methyl green ions, the overall energy balance will lead to endothermic behavior. $\Delta G^{\circ}$ was negative as expected for a spontaneous process under the conditions applied. The decrease in $\Delta G^{\circ}$ with the increase of temperature implied the adsorption process enhancement at higher temperatures where anions are readily dehydrated and their adsorption becomes more favorable. The positive value of $\Delta S^{\circ}$ reflected the affinity of the used adsorbents toward methyl green anions in aqueous solutions and may suggest some structural changes in adsorbents (Genç-Fuhrman et al. 2004; Altundoan et al. 2000) under the studied conditions.

The rate constants $\left(k_{1}\right.$ and $\left.k_{2}\right)$ of the pseudo-first and second-order models, with respect to the adsorbent, were adopted to calculate the activation energy of the adsorption process using the Arrhenius equation (Doan and Alkan 2003):

$\ln \left(k_{i}\right)=\ln (A)-\left(E_{\mathrm{a}} / R T\right)$

where $k_{i}, A, E_{\mathrm{a}}, R$ and $T$ are the rate constants of the pseudo-first-order model $\left(\mathrm{min}^{-1}\right)$ or second-order model
( $\mathrm{g} / \mathrm{mg} \mathrm{min}$ ), the Arrhenius factor, the activation energy $(\mathrm{kJ} /$ $\mathrm{mol})$, the gas constant $(8.314 \mathrm{~J} / \mathrm{mol} \mathrm{K})$ and the temperature $(\mathrm{K})$, respectively. The activation energy could be determined from the slope of the plot of $\ln \left(k_{1}\right)$ or $\ln \left(k_{2}\right)$ versus $1 /$ $T$. The activation energy of the adsorption of methyl green onto CNTs and $\mathrm{NiFe}_{2} \mathrm{O}_{4}-\mathrm{CNTs}$ was 8.98 and $21.4 \mathrm{~kJ} / \mathrm{mol}$, respectively as shown in Table 3 . These activation energies as well as the $\Delta H^{\circ}, \Delta G^{\circ}$ and $\Delta S^{\circ}$ values lead to the same conclusion: the adsorption of methyl green onto CNTs and $\mathrm{NiFe}_{2} \mathrm{O}_{4}-\mathrm{CNTs}$ is a physisorption process (Nollet et al. 2003). It was reported that the activation energy of adsorption of diffusion-controlled processes is less than 25-30 kJ/mol (Lazaridis and Asouhidou 2003).

Based on the activation energy values and the intraparticle diffusion model results, as shown in Table 3 and Fig. 10e, f, it is believed that the adsorption process involves intraparticle diffusion though this was not the only rate-controlling step and other kinetics models might affect the adsorption rate.

\section{Conclusions}

Multi-walled CNTs were synthesized by CVD method from acetylene then purified and functionalized using 
mixture of concentrated acids. $\mathrm{NiFe}_{2} \mathrm{O}_{4}-\mathrm{CNT}$ composites were synthesized using an in-situ hydrothermal method. The prepared composite exhibited a homogeneous dispersion of CNTs in the matrix with a $\mathrm{NiFe}_{2} \mathrm{O}_{4}$ nanoparticles coating. This study investigated the removal of methyl green from aqueous solutions using CNTs and $\mathrm{NiFe}_{2} \mathrm{O}_{4^{-}}$ CNTs absorbent composites. The amount of dyes adsorbed per unit of adsorbent mass increased with increasing initial dye and adsorbent concentrations and temperature. The adsorption kinetics of methyl green onto CNTs was controlled by the pseudo second-order model and by the pseudo-first-order model in the case of adsorption onto $\mathrm{NiFe}_{2} \mathrm{O}_{4}$-CNTs. The equilibrium adsorption data fit to the Langmuir isotherm. The thermodynamics of the adsorption process revealed that it was an endothermic, spontaneous and physisorption process. This study showed that CNTs and $\mathrm{NiFe}_{2} \mathrm{O}_{4}$-MWCNTs are efficient adsorbents for the removal of methyl green from wastewater.

Open Access This article is distributed under the terms of the Creative Commons Attribution License which permits any use, distribution, and reproduction in any medium, provided the original author(s) and the source are credited.

\section{References}

Altundoan HS, Altundoan S, Tümen F, Bildik M (2000) Arsenic removal from aqueous solutions by adsorption on red mud. Waste Manag 20:761-767

Bahgat M, Farghali AA, El Rouby WMA, Khedr MH (2011) Synthesis and modification of multi-walled carbon nano-tubes (MWCNTs) for water treatment applications. J Analyt Appl Pyrol 92:307-313

Banerjee SS, Chen DH (2007) Fast removal of copper ions by gum arabic modified magnetic nano-adsorbent. J Hazard Mater 147:792-799

Bansal RC (2005) Activated carbon adsorption. CRC Press, Boca Raton

Correa-Duarte MA, Grzelczak M, Salgueiriño-Maceira V, Giersig M, Liz-Marzán LM, Farle M, Sierazdki K, Diaz R (2005) Alignment of carbon nanotubes under low magnetic fields through attachment of magnetic nanoparticles. J Phys Chem B 109:1906019063

Demirbas E, Dizge N, Sulak M, Kobya M (2009) Adsorption kinetics and equilibrium of copper from aqueous solutions using hazelnut shell activated carbon. Chem Eng J 148:480-487

Doan M, Alkan M (2003) Adsorption kinetics of methyl violet onto perlite. Chemosphere 50:517-528

Feng Z, Shao Z, Yao J, Huang Y, Chen X (2009) Protein adsorption and separation with chitosan-based amphoteric membranes. Polymer 50:1257-1263

Gao C, Li W, Morimoto H, Nagaoka Y, Maekawa T (2006) Magnetic carbon nanotubes: synthesis by electrostatic self-assembly approach and application in biomanipulations. J Phys Chem B 110:7213-7220

Gauden PA, Terzyk AP, Rychlicki G, Kowalczyk P, Lota K, Raymundo-Pinero E, Frackowiak E, Béguin F (2006) Thermodynamic properties of benzene adsorbed in activated carbons and multi-walled carbon nanotubes. Chem Phys Lett 421:409-414
Genç-Fuhrman H, Tjell JC, McConchie D (2004) Adsorption of arsenic from water using activated neutralized red mud. Environ Sci Technol 38:2428-2434

Gregg S, Sing K (1982) Adsorption, surface area and porosity. Academic Press, New York

Hall K, Eagleton L, Acrivos A, Vermeulen T (1966) Pore- and soliddiffusion kinetics in fixed-bed adsorption under constant-pattern conditions. Ind Eng Chem Fundam 5:212-223

Ho YS, McKay G (2003) Sorption of dyes and copper ions onto biosorbents. Process Biochem 38:1047-1061

Hu X, Dong S (2008) Metal nanomaterials and carbon nanotubessynthesis, functionalization and potential applications towards electrochemistry. J Mater Chem 18:1279-1295

Jia B, Gao L, Sun J (2007) Self-assembly of magnetite beads along multiwalled carbon nanotubes via a simple hydrothermal process. Carbon 45:1476-1481

Kong J, Franklin NR, Zhou C, Chapline MG, Peng S, Cho K, Dai H (2000) Nanotube molecular wires as chemical sensors. Science 287:622-625

Langmuir I (1918) The adsorption of gases on plane surfaces of glass, mica and platinum. J Am Chem Soc 40:1361-1403

Lazaridis N, Asouhidou D (2003) Kinetics of sorptive removal of chromium(VI) from aqueous solutions by calcined $\mathrm{Mg}-\mathrm{Al}-\mathrm{CO}_{3}$ hydrotalcite. Water Res 37:2875-2882

LeVan MD, Vermeulen T (1981) Binary Langmuir and Freundlich isotherms for ideal adsorbed solutions. J Phys Chem $85: 3247-3250$

Li YH, Wang S, Zhang X, Wei J, Xu C, Luan Z, Wu D (2003) Adsorption of fluoride from water by aligned carbon nanotubes. Mater Res Bull 38:469-476

Liu J, Rinzler AG, Dai H, Hafner JH, Bradley RK, Boul PJ, Lu A, Iverson T, Shelimov K, Huffman CB (1998) Fullerene pipes. Science 280:1253-1256

Liu C, Fan Y, Liu M, Cong H, Cheng H, Dresselhaus M (1999) Hydrogen storage in single-walled carbon nanotubes at room temperature. Science 286:1127-1129

Liu Z, Dai X, Xu J, Han B, Zhang J, Wang Y, Huang Y, Yang G (2004) Encapsulation of polystyrene within carbon nanotubes with the aid of supercritical $\mathrm{CO}_{2}$. Carbon 42:458-460

Long RQ, Yang RT (2001) Carbon nanotubes as superior sorbent for dioxin removal. J Am Chem Soc 123:2058-2059

Ma W, Ya FQ, Han M, Wang R (2007) Characteristics of equilibrium, kinetics studies for adsorption of fluoride on magnetic-chitosan particle. J Hazard Mater 143:296-302

Mall ID, Srivastava VC, Agarwal NK (2006) Removal of Orange-G and Methyl Violet dyes by adsorption onto bagasse fly ashkinetic study and equilibrium isotherm analyses. Dyes Pigments 69:210-223

Ngomsik AF, Bee A, Siaugue JM, Cabuil V, Cote G (2006) Nickel adsorption by magnetic alginate microcapsules containing an extractant. Water Res 40:1848-1856

Nollet H, Roels M, Lutgen P, Van der Meeren P, Verstraete W (2003) Removal of PCBs from wastewater using fly ash. Chemosphere 53:655-665

Peng X, Li Y, Luan Z, Di Z, Wang H, Tian B, Jia Z (2003) Adsorption of 1,2-dichlorobenzene from water to carbonnanotubes. Chem Phys Lett 376:154-158

Peng X, Chen J, Misewich JA, Wong SS (2009) Carbon nanotubenanocrystal heterostructures. Chem Soc Rev 38:1076-1098

Rocher V, Siaugue JM, Cabuil V, Bee A (2008) Removal of organic dyes by magnetic alginate beads. Water Res 42:1290-1298

Treacy M, Ebbesen T, Gibson J (1996) Exceptionally high Young's modulus observed for individual carbon nanotubes. Nature 381:678-680

Weber W, Morris J (1963) Kinetics of adsorption on carbon from solution. J Sanit Eng Div Am Soc Civ Eng 89:31-60 
Wildoer JWG, Venema LC, Rinzler AG, Smalley RE, Dekker C (1998) Electronic structure of atomically resolved carbon nanotubes. Nature 391:59-62

Yang K, Zhu L, Xing B (2006) Adsorption of polycyclic aromatic hydrocarbons by carbon nanomaterials. Environ Sci Technol 40:1855-1861
Yang GW, Gao GY, Wang C, Xu CL, Li HL (2008a) Controllable deposition of Ag nanoparticles on carbon nanotubes as a catalyst for hydrazine oxidation. Carbon 46:747-752

Yang N, Zhu S, Zhang D, Xu S (2008b) Synthesis and properties of magnetic $\mathrm{Fe}_{3} \mathrm{O}_{4}$-activated carbon nanocomposite particles for dye removal. Mater Lett 62:645-647 